\title{
RESTORASI IDEOLOGI PANCASILA DALAM PEMIKIRAN AHMAD SYAFI'I MA'ARIF
}

\author{
Nurbani Yusuf \\ PPKn FKIP Universitas Muhammadiyah Malang, Indonesia \\ Email: nurbani@umm.ac.id
}

\begin{abstract}
ABSTRAK
Penelitian ini membahas mengenai restorasi pemikiran Ahmad Syafii Maarif selaku anggota dewan Pengarah Badan Pembinaan Ideologi Pancasila terhadap Pancasila sebagai ideologi. Pendekatan yang digunakan dalam penelitian ini adalah pendekatan kualitatif. Sedangkan metode penelitian adalah deskriptif. Adapun hasil dalam penelitian ini adalah Restorasi Ideologi Pancasila dalam pemikiran Anggota Dewan Pengarah Badan Pembinaan Ideologi Pancasila yakni Ahmad Syaf'I Ma'arif merupakan usaha berpikir kritis dalam mengejawantahkan dan mengembangkan ideologi Pancasila agar mampu bertahan dengan kondisi perubahan zaman. Pengejawantahan yang di lakukan oleh Ahmad Syaf'I Ma'arif merupakan suatu bentuk pemikiran yang sistematis, metodis dan valid dalam mengembangkan ideologi Pancasila agar dapat tetap relevan dengan kondisi dan tantangan zaman. Dengan tujuan agar ideologi Pancasila dapat terus membumi atau dapat di tarik kebumi sehingga Pancasila sebagai ideologi negara dapat benar-benar menjadi pedoman dalam kehidupan bermasyarakat, berbangsa, dan bernegara. Sehingga tujuan akhir yakni keadilan sosial bagi seluruh rakyat Indonesia dapat segera atau mengalami percepatan dalam laju gerak langkah negara ini.
\end{abstract}

Kata Kunci: Restotasi Ideologi; Pancasila; Ahmad Syaf'I Ma'arif.

\begin{abstract}
This study discusses the restoration of Ahmad Syafii Maarif's thought as a member of the Agency Steering Committee for Pancasila Ideology Education. The approach used in this study is a qualitative approach. While the research method is descriptive. The results in this study are the Restoration of Pancasila Ideology in the thought of Ahmad Syaf'I Ma'arif as a member of the Agency Steering Committee of the Pancasila Ideology Education, which is an effort to think critically in embodying and developing the Pancasila ideology so that it can stay relevant in today's conditions and/or today's challenges. The manifestation carried out by Ahmad Syaf'I Ma'arif is a form of systematic, methodical and valid thinking in developing the Pancasila ideology so that it can remain relevant to the conditions and challenges of the times. With the aim that the Pancasila ideology can continue to be grounded or be grounded so that Pancasila as the state ideology can truly become a guideline in the life of society, nation and state. So that the final goal, namely social justice for all Indonesia's citizens, can immediately experience an acceleration in the pace of this country's steps.
\end{abstract}

Keywords: Ideological Restotation; Pancasila; Ahmad Syaf'I Ma'arif.

\section{PENDAHULUAN}

Mengabaikan Pancasila dalam

kehidupan berbangsa dan bernegara akan membuat bangsa ini kehilangan arah. Lihat bagaimana dinamika sosial politik di era pasca reformasi-muncul berbagai ketegangan dan konflik yang mengancam pada perpecanahan dan keutuhan Negara Kesatuan Republik Indonesia (NKRI). Seperti kasus yang mengandung unsur
SARA di Tanjung Balai, Medan, Sumatera Utara pada Jumat 29 Juli 2016 dapat menjadi salah satu contoh konflik horizontal dan mengancam perpecanahan serta keutuhan Negara Kesatuan Republik Indonesia (NKRI) (Apinino, 2018).

Hal-hal tersebut tentu memuncul kegalauan dalam merumuskan masa depan atau kegamangan dalam melihat percaturan ideologi dunia di Negara- 
negera berkembang, seperti Indonesia. Masyarakat di era pasca reformasi sekarang ini seolah mencari jalan alternatif baru untuk menemukan atau mencocokan ideologiideologi yang berasal dari luar dalam menjawab permasalahan-permasalahan yang terjadi di kehidupannya, namun sejatinya hal-hal tersebut malah justru menimbulkan permasalahan baru karena tidak memiliki kecocokan dengan kultur kebudayaan di Indonesia yang multi etnis. Kemajemukan yang miliki Indonesia sejatinya merupakan suatu kekuatan yang apabila persatuan dan kesatuan ini goyah dapat dijadikan kelemahan (Nanggala, 2020).

Menurut hasil survei Badan Nasional Penanggulangan Terorisme pada tahun 2017 menyebutkan 39\% mahasiswa dari berbagai perguruan tinggi di Indonesia telah terpapar paham radikal. Lebih lanjut $24 \%$ mahasiswa dan 23,3\% pelajar tingkat Sekolah Menengah Atas pun setuju dengan jihad dan pembentukan negara islam atau khilafah (Budi, 2018). Senada dengan data tersebut, hasil survei yang dilakukan oleh Lingkaran Survei Indonesia Denny J.A. menyebutkan telah terjadi penurunan kepercayaan publik terhadap ideologi negara, pada tahun 2005 publik yang proPancasila angkanya mencapai $85,2 \%$, tahun 2010 menjadi 79,4\%, tahun 2015 angkanya menjadi 79,4\% dan di tahun 2018 menjadi $75,3 \%$. Dalam waktu 13 tahun, publik yang pro-Pancasila mengalami penurunan sebanyak $10 \%$. Sedangkan publik yang pro-NKRI bersyariah islam mengalami kenaikan sebanyak 9\% (Hidayat, 2018).

Sejak rezim Orde Baru tumbang muncul phobia terhadap Pancasila, Dasar Negara itu untuk sesaat dilupakan, dipinggirkan bahkan ditinggalkan karena Pancasila selalu di identikan dengan rezim orde baru-sebuah rezim yang tumbang akibat reformasi. Tampaknya ada semacam trauma mendalam terhadap perlakuan eksesif terhadap Pancasila. Dasar Negara itu berubah menjadi ideologi tunggal dan satu-satunya sumber nilai serta kebenaran. Negara menjadi maha tahu mana yang benar dan mana yang salah. Nilai-nilai itu ditanam di benak masyarakat melalui indoktrinasi (As'ad, 2009).

Pasca reformasi, pencarian jalan keluar sebagaialternatifpenyeleseianmasalahtersebut mengarah kepada melupakan Pancasila sebagai pandangan hidup serta ideologi negara dan melihat ideologi alternatif lain dalam menyeleseikan berbagai permasalahan yang di hadapi. Sebagai contoh misalnya gerakan Hizbut Tahrir Indonesia yang merupakan salah satu gerakan Islam kontemporer yang cukup besar pengaruhnya di dunia Islam. Berbeda dengan gerakan Islam lainnya, Hizbut Tahrir mengklaim dirinya sebagai partai politik. Namun berbeda dengan partai politik pada umumnya, Hizbut Tahrir adalah partai politik Islam yang berbasis pada transnasionalisme, sehingga berhubungan dengan cita-cita politiknya yang mengupayakan seluruh dunia Islam berada di dalam satu sistem kekuasaan politik yang disebut dengan Khilafah (Azman, 2018).

Pendidikan politik yang seharusnya dilakukan oleh partai politik kepada masyarakat sebagai usaha sosialisasi politik terhadap ideologi Pancasila sendiri nyatanya tenggelam dalam hiruk pikuk perebutan kekuasaan. Padahal sudah diatur dalam Undang-Undang Nomor 2 Tahun 2011 tentang Perubahan Atas UndangUndang Nomor 2 Tahun 2008 tentang Partai Politik dimana Partai Politik menerima bantuan keuangan dari APBN/APBD untuk melakukan kegiatan pendidikan politik. Akan tetapi karena pemahaman mengenai pendidikan politik sangat lentur dan tidak ada pertanggungjawaban untuk substansinya maka efektivitas program tersebut belum dapat teruji (Wibowo, 2020).

Padahal organisasi partai politik dapat dijadikan sarana dan wadah pembelajaran nilai-nilai Pancasila secara informal kepada masyarakat, karena 
didalam organisasi melalui program kerja yang dimilikinya terdapat proses-proses transformasi nilai yang akan berpengaruh kepada pembentukan watak warga Negara berdasarkan Pancasila yang merupakan bagian dari warganegara dalam kehidupan bermasyarakat, berbangsa, dan bernegara (Wibowo et al., 2016).

Pancasila sebagai das sollen dalam usaha-usaha menemukan stelsel dan mekanisme demokrasi yang cocok bagi masyarakat Indonesia sangat dihargai. Namun, pada tataran das sein bukan sesuatu yang mudah dijelmakan. Hal itu disebabkan perpaduan-perpaduan konseptual ternyata tidak disertai dengan penjabaran mengenai rule of the game yang juga menggambarkan perpaduan tersebut. Selain itu, tingkah laku politik turut memberikan kontribusi yang serius. Akibatnya, para pelaku demokrasi bebas menciptakan rule of the game menurut paham dan pengetahuan yang memengaruhi diri mereka serta keinginan-keinginan politik yang hendak dicapai (Manan \& Harijanti, 2014).

Kehidupan berpolitik bangsa Indonesia yang diwakili oleh tata kelola partai politik masih jauh dari keadaan yang ideal. Pertama, partai politik yang menjadi salah satu pilar utama kehidupan berdemokrasi dan berpolitik masih harus terus berproses dalam menjalankan amanat sebagai penyalur aspirasi masyarakat. Kedua, partai politik belum menjadikan pendidikan politik sebagai sorotan utama (Wibowo dan Wahono, 2017).

Dalam penelitiannya Asrori (2017) sekurang-kurangnya melihat ada 3 faktor, yakni pertama, perkembangan di tingkat global,Kedua, penyebaran paham Wahabisme dan yang ketiga adalah kemiskinan. Situasi yang kacau di negara-negara Timur Tengah khususnya di Afghanistan, Palestina, Irak, Yaman, Mesir, Syiria, dan Turki, dipandang oleh kelompok-radikal sebagai akibat dari campur tangan Amerika, Israel, dan sekutunya. Pada saat yang sama, Masuknya faham Wahabisme yang mengagungkan budaya Islam ala Arab yang konservatif ke
Indonesia telah ikut mendorong timbulnya kelompok eksklusif yang sering menuduh orang lain yang berada di luar kelompok mereka sebagai musuh, kafir dan boleh diperangi. Faktor ketiga adalah kemiskinan. Meski faktor ini tidak secara langsung berpengaruh terhadap merebaknya aksi radikalisme, namun perasaan sebagai elemen masyarakat yang termarjinalkan dapat menjadi faktor pendorong bagi seseorang untuk terjebak dalam proganda radikalisme.

Padahal Pancasila menurut Kaelan secara ilmiah merupakan satu objek pembahasan di mana Pancasila merupakan hasil budaya bangsa Indonesia sendiri. Pancasila karena perlakuan seperti itu pada akhirnya berbenturan dengan sumbersumber norma atau ideologi yang hidup dimasyarakatseperti sosialisme, kapotalisme dan terutama islam sebagai agama yang di peluk mayoritas bangsa Indonesia. Benturan itu tidak hanya pada level gagasan, bahkan manjalar menjadi benturan sosial-politik. Contohnya pemaksaan asas tunggal bagi parpol dan ormas, penangkapan terhadap mereka yang tidak setuju pada asas tunggal dan lain-lain, trauma itu masih belum lenyap hingga sekarang.Namun demikian mengabaikan Pancasila adalah sebuah kesalahan. Pancasila adalah dasar resmi kenegaraan. Pancasila adalah milik semua warga Negara, karena itu adalah layak dan penting mempelajari dan mengkontekstualisasikan Pancasila secara terus menerus (Kaelan, 1993).

Dalam filsafat Pancasila, terdapat tiga tingkatan yaitu nilai dasar, nilai instrumental, dan nilai praktis. Pertama, nilai-nilai dasar dari Pancasila adalah nilai ketuhanan, nilai kemanusiaan, nilai persatuan, nilai kerakyatan, dan nilai keadilan; Kedua, nilai instrumental, adalah nilai yang berbentuk norma sosial dan norma hukum yang selanjutnya akan terkristalisasi dalam peraturan dan mekanisme lembagalembaga negara; dan Ketiga, nilai praktis, 
adalah nilai yang sesungguhnya kita laksanakan dalam kenyataan. Nilai ini merupakan batu ujian apakah nilai dasar dan nilai instrumental itu benar-benar hidup dalam masyarakat.

Restorasi Pancasila sebagai faktor intergratif dan salah satu fundamen identitas nasional perlu digagas kembali. Gagasan demikian tampak signifikan karena proses amandemen UUD 1945 sempat memunculkan gagasan menghidupkan kembali Piagam Jakarta. Indonesia juga dilanda gerakan terorisme mengatasnamakan agama. Kemudian muncul Perda Syari'ah di sejumlah daerah, gerakan separatism di sejumlah propinsi seakan melangkapi kegelisahan publik selama reformasi yang mempertanyakan arah gerakan reformasi dan demokratisasi. Azrumardi Azra menyerukan kembali gagasan tentang revitalisasi Pancasila sebagai Ideologi dan Falsafah bangsa banyak direspon berbagai lapisan masyarakat terutama kalangan akademisi dan politisi.

Dengan alasan itu maka sangatlah wajar bila diskursus tentang Pancasila dihidupkan lagi; bukan untuk mengulang sejarah melainkan bagaimana meletakkan kembali Pancasila secara proporsional dan kontekstual dengan semangat zaman. Berbeda dengan masa Orde baru yang mengharamkan segala bentuk perbedaan tafsir tentang Pancasila karena pemerintah yang paling berhak memberi tafsir atasnya maka pada saat era pasca reformasi ini telah menghasilkan sejumlah wacana dan bahasan menarik yang perlu dicermati dan disimak.

\section{METODE}

Pendekatan yang digunakan dalam penelitian ini adalah pendekatan kualitatif. Sedangkan metode penelitian adalah deskriptif. Hakekat penelitian kualitatif adalah merupakan penelitian yang bermaksud memahami fenomena tentang apa yang dialami oleh subjek penelitian misalnya perilaku, presepsi, motivasi, tindakan dan lain secara holistic dan dengan cara deskripsi dalam bentuk kata-kata dan bahasa, pada suatu konteks khusus yang alamiah dan dengan memanfaatkan berbagai metode alamiah (Dewantara, 2011).

Oleh karena itu penelitian kualitatif ini pula dapat disebut juga sebgaai penelitian naturalistik, karena data yang dikumpulkannya bercorak kualitatif dan bukan kuantitatif yang dapat di ukur dengan menggunakan alat-alat tertentu. Sehingga penelitian ini bersifat natural atau apa adanya tanpa dimanipulasi (Rahmat, 2009).

Adapun yang menjadi subyek dalam penelitian ini adalah Ahmad Syafii Maarif sebagai Anggota Dewan Pengarah Badan Pembinaan Ideologi Pancasila pada Tahun 2018-2019. Selanjutnya data dikumpulkan dengan cara melakukan wawancara, observasi, dan studi dokumentasi dengan analisis data pengumpulan data, reduksi data, penyajian data, verifikasi data. Sedangkan teknik dalam pengolahannya dilakuakn dengan triangulasi data agar dapat membandingkan, mengecek balik kepercayaan informasi yang diperoleh.

\section{HASIL DAN PEMBAHASAN \\ Pemikiran Ahmad Syafi'i Ma'arif Terhadap Restorasi Ideologi Pancasila}

Hasil temuan di lapangan, pemikiran Ahmad Syafii Maarif terhadap restorasi ideologi Pancasila selaku anggota dewan pengarah Badan Pembinaan Ideologi Pancasila memang berfokus terhadap pengembalian atau pemulihan kembali nilai-nilai ideologi Pancasila dalam menghadapi tantangannya yang dewasa ini semakin tergerus oleh perkembangan zaman. Pemikiran Ahmad Syaf'i Ma'arif sebagai Anggota Dewan Pengarah Badan Pembinaan Ideologi Pancasila tersebut berusaha menyesuaikan nilai-nilai yang terkandung dalam Pancasila dengan keadaan dan tantangan zaman yang semakin berubah tanpa mengubah nilainilai dasar yang terkandung didalamnya.

Hal tersebut Ahmad Syafi'I Ma'arif 
jelaskan dengan mengatakan Indonesia sebagai bangsa itu belum menjadi, masih dalam proses menjadi. Pancasila sebagai ideologi dan dasar negara sejatinya sudah dalam posisi yang kokoh. Walaupun masih terdapat kelompok-kelompok kecil yang menolak Pancasila, namun tidak memberikan dampak yang cukup signifikan. Hanya berupa riak-riak kecil dalam kehidupan bermasyarakat, berbangsa, dan bernegara. Walaupun hanya berupa riakriak kecil, namun harus tetap menjadi fokus perhatian seluruh elemen bangsa baik pemerintah maupun civil society yang konsisten terhadap ideologi Pancasila. Hal ini demi mempertahankan dan melihat Indonesia sampai masa yang akan datang nanti.

Ahmad Syafi'I Ma'arif lebih lanjut menjelaskan bagaimana sejatinya suasana kebatinan yang terjadi di dalam Badan Persiapan Usaha Kemerdekaan Indonesia. Dimana pada saat itu Bangsa Indonesia dihadapkan pada tiga pilihan, yakni Islam, Pancasila, dan SosialEkonomi. Yang kemudian Sosial-Ekonomi itu pendukungnya tidak banyak, lalu bergabung ke Pancasila. Kita seharusnya merasa beruntung punya filsafat Pancasila yang hebat, digali oleh Bung Karno tanpa teks pada 1 Juni 1945. Yang menjadi persoalan Pancasila dewasa ini adalah Sila ke Lima yakni "keadilan sosial bagi seluruh rakyat Indonesia" yang belum menjadi pedoman dalam membangun bangsa sejak kita merdeka.

Dari hasil pemikiran tersebut (Aco, 2016) jelaskan bahwa Pancasila sebagai ideologi memiliki sifat yang terbuka. Hal ini berarti Pancasila dapat menerima dan mengembangkan pemikiran baru dari luar dan dapat berinteraksi dengan perkembangan/ perubahan zaman dan lingkungannya, bersifat demokratis dalam arti membuka diri masuknya budaya luar dan dapat menampung pengaruh nilainilai dari luar yang akan di inkorporasi, untuk memperkaya aneka bentuk dan ragam kehidupan bermasyarakat Indonesia juga memuat dimensi-dimensi secara menyeluruh.

Sifat terbuka yang dimiliki oleh ideologi Pancasila tersebut bila dilihat berdasarkan teori causalitas, causa materialis Pancasila berasal dari adat kebiasaan, kebudayaan, dan agama yang ada di Indonesia. Dengan demikian, tidak dapat diragukan bahwa dasar negara yang kita miliki digali dari nilai yang terdapat dalam masyarakat. Nilai tersebut tersebar pada masyarakat, digunakan untuk mengatur kehidupan masyarakat. oleh karena itu, tidak diragukan lagi bahwa Pancasila sebenarnya merupakan budaya dan pembudayaan bangsa Indonesia yang perlu dipahami secara ilmiah oleh bangsa Indonesia (Amien, 2006).

Ideologi Pancasila sejak semula mengandung sifat dan ciri keterbukaan, yang mampu menampung serta menghargai berbagi aspirasi yang tumbuh dari segenap bagian dari kepulauan nusantara, dan menuangkannya ke dalam intisari yang mewadahi keragaman aspirasi tersebut dalam dalam kesatuan orientasi yang tumbuh dan padat (Supriyatno, 1995). Keterbukaan ideologi bukan saja merupakan suatu penegasan kembali dari pola pikir yang dinamis dari para pendiri negara kita dalam tahun 1945, tetapi juga merupakan suatu kebutuhan konseptual dalam dunia modern yang berubah dengan cepat (Lanur, 1995).

Ideologi terbuka hanyaberisi orientasi dasar, sedangkan penerjemahannya ke dalam tujuan-tujuan dan norma-norma sosial-politik selalu dapat dipertanyakan dan disesuaikan dengan nilai dan prinsip moral yang berkembang di masyarakat. Operasional cita-cita yang akan dicapai tidak dapat ditentukan secara apriori, melainkan harus disepakati secara demokratis. Dengan sendirinya ideologi terbuka bersifat inklusif, tidak totaliter dan tidak dapat dipakai melegitimasi kekuasaan sekelompok orang. Ideologi terbuka hanya dapat ada dan 
mengada dalam sistem yang demokratis (Maimun, 2000).

Perbincangan kefilsafatan Ideologi

Pancasila tersebut karena Pancasila sebagai sistem filsafat telah memenuhi tiga teori kebenaran, yakni teori kebenaran koherensi, korespondensi, dan pragmatik. Teori koherensi, menurut teori ini, pernyataan dianggap benar jika pernyataan bersifat konsisten dengan pernyataan sebelumnya yang dianggap benar. Setiap sila Pancasila di dalamnya mengandung sila yang lainya. Terdapat hubungan yang saling mengkualifikasi. Ketuhanan Yang Maha Esa adalah ketuhanan yang berkemanusiaan, berpersatuan, berkerakyatan, dan berkeadilan. Begitu seterusnya dengan sila yang lain pula. Hubungan satu kesatuan dan saling mengkualifikasi ini terjadi karena tidak ada pertentangan sila yang satu dengan sila yang lainnya, hubungan sila kesatu sampai sila kelima bersifat runtut. Inilah satu penerapan teori koherensi.

Teori korespondensi, menurut teori ini, satu pernyataan benar jika materi pengetahuan yang dikandung pernyataan itu berhubungan dengan objek yang dituju oleh pernyataan tersebut. Menurut Notonagoro, ada hubungan yang mutlak antara Pancasila dengan bangsa Indonesia, yaitu hubungan sebab-akibat. Maka kebenaran menurut sistem filsafat Pancasila, bahwa kandungan pernyataan sila-sila Pancasila harus cocok, sesuai, terjelma dalam keadaan senyatanya bermasyarakat dan bernegara. Sila-sila dalam Pancasila berkesesuaian atau kores pondensi dengsn objek yang dituju.

Teori pragmatik, menurut teori ini, nilai kebenaran proposisi diukur dengan kriteria apakah proposisi tersebut berfungsi dalam kehidupan praksis atau tidak. Teori ini tercermin dalam Pancasila sebagai pemersatu bangsa Indonesia. Hal ini menunjukan bahwa sistem filsafat Pancasila berfungsi secara praktis (Budisutrisna, 2017). Sehingga Pancasila sebagai ideologi memiliki sifat universal dan objektif ilmu untuk mencapai kenyataan dalam objektivitas segala sesuatu dalam dirinya (nilai ontologis) dan dalam hubungannya dengan manusia berupa kebenaran (nilai logis) (Mudhofir, 2006).

Ahmad Syaf'I Ma'arif memaparkan tentang persoalannya sudah bukan lagi antara Islam dan Pancasila. Melainkan Pancasila itu masih di atas, di awan yang sangat tinggi. Yang artinya keadilan belum tegak dan kesenjangan sosial di negara Indonesia ini masih sangat tajam sekali. Padahal jikalau kembali melihat Pidato 1 Juni 1945, Bung Karno menjelaskan "di dalam Indonesia merdeka tidak akan ada lagi kemiskinan". Artinya yang menjadi urgensitas ideologi Pancasila saat ini adalah bagaimana membawa nilai-nilai Pancasila ini turun ke bumi, sehingga Sila kelima dalam Pancasila yakni "keadilan sosial bagi seluruh rakyat Indonesia" dapat dirasakan oleh seluruh masyarakat.

Bila melihat pemikiran kedua tokoh Badan Pembinaan Ideologi Pancasila tersebut selaras dengan Koento Wibisono (dalam Bakry, 2001) yang menyatakan bahwa untuk mengembangkan Pancasila, pertama harus ada unsur keyakinan. Setiap ideologi selalu memuat konsep-konsep dasar yang menggambarkan seperangkat keyakinan yang diorientasikan kepada tingkah laku para pendukungnya untuk mencapai suatu tujuan yang dicita-citakan.

Pengejawantahan yang di lakukan oleh Ahmad Syafi'i Ma'arif tersebut merupakan suatu bentuk dukungan yang dilakukannya dalam mengembangkan ideologi Pancasila agar dapat tetap relevan dengan kondisi dan tantangan zaman. Dengan tujuan agar ideologi Pancasila dapat terus membumi atau dapat di tarik kebumi sehingga Pancasila sebagai ideologi negara dapat benar-benar menjadi pedoman dalam kehidupan bermasyarakat, berbangsa, dan bernegara. Sehingga tujuan akhir yakni keadilan sosial bagi seluruh rakyat Indonesia dapat segera atau mengalami percepatan 
dalam laju gerak langkah negara ini.

Lebih lanjut Koento Wibisono (dalam Bakry, 2001) menjelaskan unsur yang kedua, adalah unsur mitos. Setiap ideologi selalu memitoskan ajaran dari seseorang atau "badan" sebagai kesatuan, yang secara fundamental mengajarkan cara bagaimana hal yang ideal itu pasti dapat dicapai. Hal ini pula yang dilakukan oleh kedua tokoh Badan Pembinaan Ideologi Pancasila Ahmad Syafi'I Ma'arif dan Yudi Latief. Mitos yang peneliti pahami bukan lah suatu hal yang gaib, melainkan kedua tokoh tersebut menggunakan peristiwaperistiwa sejarah di masa lampau sebagai media dalam setiap syiar kebangsaan yang mereka lakukan.

Berdasarkan hasil temuan di lapangan, syiar-syiar kebangsaan atau sosialisasi mengenai ideologi Pancasila yang Ahmad Syafi'I Ma'arif lakukan menggunakan berbagai macam forum yang dalam setiap acaranya selalu memaparkan mengenai historycal asal muasal ideologi Pancasila menjadi suatu kesepakatan bersama. Dalam setiap isi pemaparan mengenai ideologi Pancasila, keduanya selalu menjadikan Bung Karno dengan Pancasila 1 Juni 1945 sebagai tokoh utama dalam menggani ideologi Pancasila.

Terakhir Koento Wibisono (dalam Bakry, 2001) menjelaskan unsur mengembangkan ideologi Pancasila, yakni loyalitas. Setiap ideologi selalu menuntut adanya loyalitas serta keterlibatan optimal para pendukungnya untuk mendapatkan derajat penerimaan optimal. Selain itu, dalam ideologi terkandung juga adanya tiga sub-unsur, yaitu rasional, penghayatan dan susila. Ahmad Syafi'I Ma'arif dalam praktik kesehariannya yang peneliti amati masuk dalam kategori ini, kedua tokoh Badan Pembinaan Ideologi Pancasila ini merupakan tokoh yang benar-benar konsisten dan loyal dalam memberikan kontribusi pemikirannya terhadap pengembangan ideologi bangsa.

Dalam hasil observasi dan studi dokumentasi menunjukan usaha-usaha konkret yang di lakukan oleh Ahmad Syafii Maarif dalam mengembangkan ideologi Pancasila. Dalam berbagai kesempatan di mimbar akademik, karya ilmiah, dan media baik cetak maupun elektronik, Ahmad Syafi'i Ma'arif berupaya secara nyata mensosialisasikan rasionalitas ideologi Pancasila agar mendapatkan penerimaan sosial yang baik di masyarakat. Sehingga penghayatan atas sosialisasi yang dilakukan olehAhmad Syafi'i Ma'arifdapatdilaksanakan sebagai pedoman kesusilaan dalam kehidupan bermasyarakat, berbangsa, dan bernegara.

Pengembangan ideologi Pancasila yang di lakukan oleh Ahmad Syafi'I Ma'arif saat ini dijelaskan sebagai bentuk upaya dalam merasionalisasikan ideologi Pancasila dalam menanggapi tantangan dan ancaman ideologi-ideologi luar yang merangsak maksud kedalam masyarakat Indonesia. Ahmad Syafi'I Ma'arif sebagai salah satu tokoh nasional dari golongan islam memilih untuk tampil ke muka dan menangkal berbagai macam paham radikal yang dewasa inicukup memberikan kegaduhan di kalangan masyarakat. Sosialisasi tersebut Ahmad Syafi'I Ma'arif lakukan sematamata bertujuan agar Pancasila dapat menjadi tenda besar pelindung bangsa dimana semua golongan dapat hidup dibawah naungannya.

Pemikiran Anggota Dewan Pengarah Badan Pembinaan Ideologi Pancasila yakni Ahmad Syafi'i Ma'arif tersebut dapat membuktikan dasar ontologis yang di ungkapkan oleh Notonagoro (1975) yang pada hakekatnya adalah manusia. Karena manusia lah yang memiliki hakekat mutlak monopluralis, hakekat dasar ini juga disebut sebagai dasar antropologis. Subjek pendukung pokok-pokok pancasila adalah manusia itu sendiri. Demikian juga jika kita pahami dari segi filsafat negara bahwa Pancasila sebagai dasar filsafat negara, adapun pendukung pokok negara adalah rakyat dan unsur rakyat adalah manusia itu sendiri. 
Notonagoro memang tidak pernah sekalipun baik dalam tulisan maupun orasi ilmiahnya menyebutkan istilah religiusitas Pancasila ini. Kendati demikian, muatan dan makna religiusitas Pancasila ini sangat tergambar kuat pada pemikirannya tentang tiga asas yang dimiliki Pancasila, yakni; sebagai asas kulturil, asas religius, dan asas kenegaraan. Religiusitas Pancasila tidak dimaksudkan bahwa kemudian Pancasila ini menjadi "agama" bagi bangsa Indonesia. Religiusitas Pancasila yang dirumuskan dari pemikiran Notonagoro adalah fungsionalisasi asas kerohanian yang terkandung dalam Pancasila. Atas dasar Pancasila, maka Indonesia bukanlah sebuah negara sekuler dan juga bukan sebuah negara yang didominasi oleh agama dari kalangan mayoritas penduduknya (Hidayatullah, 2006).

Lebih lanjut Notonegoro (dalam Soedarso, 2006) menegaskan memang silasila daripada Pancasila mempunyai hanya satu pendukung, siapa yang berke-Tuhanan Yang Maha Esa, tiada lain daripada manusia, siapa yang berkemanusiaan yang adil dan beradap, tiada lain daripada manusia, siapa yang berpersatuan Indonesia, tiada lain daripada manusia, siapa yang berkerakyatan, lagi tiada lain daripada manusia, dan siapa yang berkeadilan sosial, pun tiada lain daripada manusia. Jadi manusialah yang menjadi pendukung atau subyek daripada sila-sila daripada Pancasila. Pancasila menjadi dasar filsafat atau dasar kerohanian Negara dari bangsa Indonesia, bangsa itu terdiri atas apa, atas manusia-manusia, dan Negara itu terdiri atas apa, atas manusiamanusia. Siapa yang berfilsafat, siapa yang berfilsafat, siapa yang berkerohanian, ialah manusia. Maka dari itu manusialah yang menjadi dasar kesatuan daripada Pancasila, dengan lain perkataan didalam Pancasila tersimpul hal-hal yang mutlak daripada manusia.

Tepatlah jika dalam filsafat Pancasila bahwa hakekat dasar antropologis sila
Pancasila adalah manusia. Manusia sebagai pendukung pokok sila-sila Pancasila secara antologis memiliki hal-hal mutlak, yaitu terdiri atas susunan kodrat, raga dan jiwa, jasmani dan rohani, sifat kodrat manusia adalah sebagai mahluk individu dan mahluk sosial, serta kedudukan kodrat manusia sebagai pribadi berdiri sendiri dan sebagai mahluk tuhan yang maha esa. Oleh karena itu, kedudukan kodrat manusia sebagai pribadi berdiri sendiri dan sebagai mahluk tuhan inilah maka secara hirarkis sila pertama Ketuhanan yang maha Esa mendasari dan menjiwai keempat sila-sila pancasila lainya.

\section{SIMPULAN}

Restorasi Ideologi Pancasila dalam pemikiran Anggota Dewan Pengarah Badan Pembinaan Ideologi Pancasila yakni Ahmad Syafi'I Ma'arif merupakan usaha berpikir kritis dalam mengejawantahkan dan mengembangkan ideologi Pancasila agar mampu bertahan dengan kondisi perubahan zaman. Tantangan-tangan yang kerap kali di hadapi oleh ideologi Pancasila tersebut dalam perubahan situasi dan kondisi ini harus tetap memiliki pendukung yang setia. Para pendukung ini tak lain adalah manusia, sebagai warga negara dari ideologi negara yang didiaminya.

Pancasila sebagai ideologi negara harus di tempatkan secara proper oleh negara, sampai hingga saatnya ideologi Pancasila dapat menjadi civic religion. Pancasila sebagai civic religion yang di maksud adalah ketika Pancasila sebagai ideologi benar-benar menjadi bintang penuntun arah jalannya perkembangan suatu negara dan masyarakatnya. Pancasila sebagai ideologi benar-benar ditempatkan secara proper dan bukan sebagai alat untuk menjatuhkan golongan atau kelompok manapun yang tidak sesuai dengan kepentingan negara.

Warga negara sebagai kumpulan manusia yang mendiami sebuah negara juga 
dapat mengetahui arah laju perkembangan proses kenegaraan yang sedang berlangsung dengan memahami ideologi yang di gunakan oleh negaranya, yakni Pancasila. Masih sesuai atau tidak sesuainya arah laju negara dapat warga negara ketahui apa bila telah memahami dan memaknai ideologi Pancasila sebagai bintang penuntun dan bukan sebagai suatu slogan semata dalam kehidupan bermasyarakat, berbangsa dan bernegara.

\section{DAFTAR PUSTAKA}

Aco,A.A. (2016). Relevansi Pancasila Sebagai Ideologi Terbuka di Era Reformasi. Jurnal Office, 2(2), 229-238.

Amien, M. M. (2006). Causa Materialis Pancasila Menurut Notonagoro. Jurnal Filsafat, 39(1), 18-26. https:// jurnal.ugm.ac.id/wisdom/article/ view/23212/15303

Apinino, R. (2018). Detail Kejadian Keluhan Suara Azan dan Kerusuhan di Tanjung Balai. Www.Tirto.Id.

As'ad, S. A. (2009). Negara Pancasila : jalan kemaslahatan berbangsa. Pustaka LP3ES.

Asrori,A. (2017). Radikalisme Di Indonesia: Antara Historisitas dan Antropisitas. KALAM， 9(2)， 253. https://doi. org/10.24042/klm.v9i2.331

Azman. (2018). Gerakan Dan Pemikiran Hizbut Tahrir Indonesia. Al-Daulah Jurnal Hukum Pidana Dan Ketatanegaraan, 7(1), 99-113.

Bakry, N. (2001). Orientasi Filsafat Pancasila. Liberty.

Budi, T. (2018). BIN: 39 Persen Mahasiswa Terpapar Paham Radikal. Www. Okezone.Com.

Budisutrisna, B. (2017). Teori Kebenaran Pancasila sebagai Dasar Pengembangan Ilmu. Jurnal Filsafat, 16(1), 57-76. https://journal.ugm.ac.id/wisdom/ article/view/23216

Dewantara, K. H., \& E-mail, S. (2011). Deskripsi Kualitatif Sebagai
Satu Metode Dalam Penelitian Pertunjukan. Harmonia: Journal of Arts Research and Education, 11(2), 173-179. https://doi.org/10.15294/ harmonia.v11i2.2210

Hidayat,F.(2018).SurveiLSI: Pro-Pancasila Turun 10\%, Pro-NKRI Bersyariah Naik 9\%. Www.Detik.Com. https:// news.detik.com/berita/d-4119173/ survei-1si-pro-pancasila-turun-10pro-nkri-bersyariah-naik-9

Hidayatullah, S. (2006). Notonagoro dan Religiusitas Pancasila. Jurnal Filsafat, 16(1), 34-41. https://doi.org/10.22146/ jf.23214

Kaelan. (1993). Pancasila Yuridis Kenegaraan. Liberty.

Lanur, A. (1995). Pancasila sebagai ideologi terbuka : problema dan tantangannya. $140 \mathrm{p}$.

Maimun. (2000). Meredam Ideologi Radikal Di Indonesia Melalui Praktik Keteladanan Nilai Pancasila Oleh Dosen Program Studi Ilmu Politik Universitas Syiah Kuala ABSTRACK People's lives are driven by the basic idea of a foundation to fight for his life. The basic idea w. Jurnal Administrasi Negara, 3(2), 26-33.

Manan, B., \& Harijanti, S. D. (2014). Artikel Kehormatan: Saat Rakyat Bicara: Demokrasi dan Kesejahteraan. Pandjadjaran Jurnal Ilmu Hukum, 1(1), 1-18. https://doi.org/https://doi. org/10.22304/pjih.v1n1.a1

Mudhofir, A. (2006). Pancasila sebagai Pokok Pangkal Sudut Pandang Bagi Ilmu Menurut Notonagoro. Jurnal Filsafat, 39(1), 27-33. https://journal. ugm.ac.id/wisdom/article/view/23213

Nanggala, A. (2020). Pendidikan Kewarganegaraan Sebagai Pendidikan Multikultural. Jurnal Soshum Insentif, 3(2), 197-210. https://doi. org/https://doi.org/10.36787/jsi.v3i2.354

Notonagoro. (1975). Beberapa Hal Mengenai Falsafah Pancasila. Pancoran Tujuh. 
Rahmat, P. S. (2009). Penelitian Kualitatif. EQUILIBRIUM, 5(9), 1-8. http:// yusuf.staff.ub.ac.id/files/2012/11/ Jurnal-Penelitian-Kualitatif.pdf

Soedarso. (2006). Pengembangan Sistem Filsafat Pancasila. Jurnal Filsafat, 39(1), 42-56. https://journal.ugm. ac.id/wisdom/article/view/23215

Supriyatno, A. (1995). Pancasila Sebagai Ideologi Terbuka (p. 140 p.).

Wibowo, A. P. (2020). The Efforts Of Demokrasi Indonesia Perjuangan Party Regional Board Struggle In Transformation Pancasila Values On Cadre. Jurnal Ilmiah Pendidikan Pancasila Dan Kewarganegaraan, 5(1), 33-41. http://journal2.um.ac.id/ index.php/jppk/article/view/12673/6096

Wibowo, A. P., Sumantri, E., \& Syaifullah. (2016). Transformasi Nilai-Nilai Pancasila Melalui Organisasi Mahasiswa Guna Meningkat Kesadaran Berbangsa Dan Bernegara (Studi Deskriptif Terhadap Organisasi Mahasiswa Jurusan Di Fakultas Pendidikan Ilmu Pengetahuan Sosial, Universitas Pendidikan Indonesia). Proceeding Internasional Seminar Pendidikan Kewarganegaraan Sebagai Bidang Keilmuan Dan Program Pendidikan Dalam Konteks Penguatan Daya Saing Lulusan, 400-411.

Wibowo, A. P., \& Wahono, M. (2017). Pendidikan Kewarganegaraan: usaha konkret memperkuat multikulturalisme di Indonesia. Jurnal Civics: Media Kajian Kewarganegaraan, 14(2), 196205. https://doi.org/10.21831/civics. v14i2.16043 